\title{
Same Plight, Different Struggle: A Comparison of Female Protagonists in Hamlet and “The Yellow Wallpaper”
}

\author{
HE Jing \\ Beijing Foreign Studies University, Beijing, China
}

\begin{abstract}
Approaching from the perspective of feminist criticism, this paper compares the female protagonists in Shakespeare's well-known tragedy Hamlet and Gilman's short story “The Yellow Wallpaper”. While the first person narrator in "The Yellow Wallpaper" is a modern signifier of the archetypal Ophelia as the sacrificial lamb of the patriarchal oppression, the two differ in their manifestations of madness, which could be accounted for by their respective historical and social environment with women’s awakening consciousness of self-identity.
\end{abstract}

Keywords: feminist criticism, Hamlet, "The Yellow Wallpaper”

\section{Introduction}

Hamlet, a masterpiece of the Renaissance tragedy and "the world's most quoted play" (Fiero, 2006, p. 147), attracted the attention of many Shakespearean scholars over the history. But compared to numerous critical texts on Hamlet and his feigned insanity to seek revenge, the overriding theme of the play, the analysis of Ophelia was seldom in the spotlight. In an attempt to better understand the reasons behind the madness of Ophelia and her final demise, this paper compares Ophelia with the narrator protagonist "I" in Gilman's unconventional short story "The Yellow Wallpaper", which describes how a woman undergoes mental deterioration and finally loses her rationality in the course of a "rest cure" prescribed for her depression. Considering the fact that both Ophelia and "I" turned mad as a result of the unbearable pressure from the patriarchal world they were exposed to, the paper resorts to feminist criticism while comparing the fate of the two female protagonists. To denote the diverging approaches of revolt by Ophelia and "I" when confronted with the same plight, the author also applies historical analysis, comparing the historical and social backgrounds of the seventeenth century Elizabethan period and the American society during the late nineteenth to early twentieth century.

\section{From Feminism to Feminist Criticism}

Feminism, which could be defined as "a belief in sexual equality combined with a commitment to eradicate sexist domination and to transform society” (Humm, 1992, p. 1), has experienced three waves of development in its historical evolution from a political movement to an interdisciplinary theory drawing upon and giving reference to various fields of studies including literacy criticism. With its revolutionary spirit originating from Mary Wollstonecraft's A Vindication of the Rights of Woman, the first wave of feminism surged from mid

HE Jing, Ph.D., Associate Professor, School of English and International Studies, Beijing Foreign Studies University. 
nineteenth century to 1920s in the form of women seeking suffrage and equal rights in education, work, and family. The second wave during 1960s and 1970s mainly focused on the prioritization of gender difference between men and women over biological difference and the "collective consciousness" of women as a group to promote social change (Wright, 1992, p. XV). While the third wave from early to mid 1980s witnessed a reoriented focus on historical and cross-cultural differences among women and experimental writings by feminist writers to subvert the dominant patriarchal language system through women's talk.

When applied to critical theory, the school of feminist criticism seeks to examine "the ways in which literature (and other cultural productions) reinforce or undermine the economic, political, social, and psychological oppression of women” (Tyson, 1999, p. 81). Feminist criticism provides a brand-new perspective of highlighting the suppressed experience of women in a male-dominant society, calling upon women to abandon their traditional gender roles as being "emotional (irrational), weak, nurturing and submissive” (Tyson, 1999, p. 83). According to feminist critics, the male camera eye as exhibited in many literary works was blind to female experience and encouraged women to "tolerate familial abuse, wait patiently to be rescued by a man, and view marriage as the only desirable reward for 'right' conduct” (Tyson, 1999, p. 87). Any attempt by women to revolt against such a fate in search of their own desires would be deemed as behaviors of insanity. Since feminist criticism highlights the subjugated fate of women in the patriarchal society with an aim to enhance women's self-consciousness for their own voice and freedom against male dominance, the theory could serve as a powerful tool in digging out the predicament of Ophelia and "I" in focus, the different reasons behind their madness and their respective choice in the revolt against the patriarchal ideology.

\section{A Feminist Interpretation of Ophelia and "I"}

From the perspective of feminist criticism, it is not difficult to find out that both Ophelia and "I" suffered from the same plight as a materialized woman in a world of male dominance. It is deep-rooted in the patriarchal society that a woman is born to be ruled by a man; they should remain faithful to men and be contented about their submission as a servant, deprived of all their desires as a subjective being. Only in this way can they be "entitled to the most splendid deification” (Beauvoir, 1949, p. 172).

As described in the beginning of Hamlet and "The Yellow Wallpaper", both Ophelia and the first person narrator enjoyed an effluent life under the careful protection of men. The beautiful Ophelia was an obedient girl to her father. Although admired and deeply attracted by Prince Hamlet, Ophelia was ready to accept her father's advice to constrain her inner feelings by keeping a distance from the Prince. Deprived of her voice and thought, Ophelia became a tool of her father to test out the real intention of Hamlet. Similarly, the narrator in "The Yellow Wallpaper" was taken good care of by her loving husband, who rented a mansion in the countryside for her to recover form illness. She was not allowed to work until she was well again and had to follow the "schedule prescription for each hour in the day" (Gilman, 1998, p. 641). According to the patriarchal understanding, such a life shouldn't be complained about, free from the pressure of work to support the family and the worry to make the decisions of life. The only thing left for women is to remain obedient to men's desires and conform to their stereotyped roles as "angel in the house" (Selden, 1989, p. 145). Therefore, Ophelia sacrificed her true love in exchange for the "protection" from her father, and "I" stopped writing except in privacy in order to please "my" husband for his love. 
But underneath the placid sea, a violent torrent was being fermented. Both Ophelia and "I" experienced the intensifying conflict between male expectation and their own desires, which finally resulted in their mental breakdown. Although both Ophelia and "I" went mad in the end, a deeper reading of the two works might reveal different reasons behind their insanity.

In the case of Ophelia, the reason lies in her gradual loss of self-consciousness as a woman and her inability to adapt to the conflict between the idealized dream and the harsh reality. Under the "protection" of a patriarchal world symbolized by her authoritative father, caring brother and passionate lover, Ophelia blindly accepted her fate as an obedient daughter, a docile sister, and a faithful worshipper. In the process of conforming to social expectations, Ophelia gradually lost her charm and self-consciousness. Unable to think, she would report everything to her father for instruction; unable to love, she was no longer attracted and trustworthy to Hamlet. Deprived of her own thought and female identity, it was no wonder that Ophelia would be driven out of her mind when her father died, her brother was far away and Hamlet's harsh words broke all her dream of marriage, the last safe haven for her to hide from the dangers of the world beyond her own control. Madness was the only way out for her to release the long-suppressed female desires in face of the nightmarish discrepancy between her dream and reality.

The narrator of "The Yellow Wallpaper", on the other hand, chose to become mad to pursue her subjectivity and female voice submerged by the patriarchal world order. Although placed in a comfortable environment by her affectionate husband, the narrator was not treated as one with equal status, but a private property at the full disposal of men. When she deemed it beneficial to take appropriate amount of work, her husband forbade her to work at all; when she felt weirdly about the fence and the locked iron door, her husband insisted that such feelings were nothing but illusions caused by the current; when she wanted to move to the room downstairs with blossoming roses at the window, her husband turned down such a request with all kinds of excuses; when she hoped to have the smelly yellow wallpaper replaced, she again met the rebuff without room for further negotiation. But unlike Ophelia who stayed obedient to men's will by sacrificing that of her own, the narrator in "The Yellow Wallpaper" never ceased the effort to fight for her own voice and the power of decision-making. Against her husband's warning not to write, she seized all possible opportunities to express her inner feelings on paper. Although her husband asked her to rest in bed and not to trouble her mind with fancy ideas, she sneaked to observe the patterns on the yellow wallpaper. It was just the narrator's refusal to stop writing and thinking that helped her gradually come to the fact that she was imprisoned in a nursery with bars and a bed nailed onto the floor. The yellow wallpaper became a symbol of the patriarchal rule over the subjectless female identity. With enhanced awareness for her husband's attempt to control her voice and thought, the narrator gradually identified herself with the woman shaking the bars, the figure she finally made out according to the pattern of the yellow wallpaper. In a patriarchal world where women were imprisoned as physical and mental slaves of men with no one to depend upon except themselves, the only way to break the shackle was through insanity, or total subversion of socially-accepted norms.

From the above analysis, it is clear to see that both Ophelia and "I" in "The Yellow Wallpaper" suffer from the same plight of being materialized by male desires, though in disguise of care and protection. But the two differed dramatically in their responses to the male oppression. Ophelia relied her entire world on the males around her and became an idealized angel living in her dreams without any sense of self-identity. Therefore, 
when left alone and suddenly exposed to the harsh reality, she resorted to madness. Compared to Ophelia, who gave up her precious life to maintain the image of a "good girl" according to the male standard, the narrator in "The Yellow Wallpaper" demonstrated great courage and determination to change from a "good girl" to a "bad girl”, an image frightened by the male world. The act to peel off the paper to let out the woman was just the narrator's attempt of discovering her true self and regaining the lost voice. Her madness was not a tragedy, but a victory over male dominance, symbolized by the fainting of her husband at the end of the story. Therefore, Ophelia's self-destruction strengthened the patriarchal agenda, while the self-salvation of the narrator constituted a frontal assault on the male domination.

\section{Socio-historical Analysis of Different Struggling Forms}

Feminist criticism, as mentioned above, could help us better understand the tragic fate of Ophelia and "I" from literary angles, the different responses of the two heroines could also be explained from the perspective of historical analysis by comparing the historical and social backgrounds of the seventeenth century Elizabethan period and the American society during the late nineteenth to early twentieth century.

The Elizabethan period had strict moral requirements for women, advocating obedience to male power and suppressing the expression of passion and erotic love. As a result, Elizabethan women were defined by purity, piety, domesticity, and docility, being considered vulnerable and in need of protection from men. From this sense, Ophelia's choice to retreat to her own dream in maniac and her final fate of being drowned accidentally, remaining chaste and loyal to her love, were readily acceptable by the readers of the time. The Elizabethans, still influenced by the patriarchal ideology, "would have been prepared to accept Ophelia as a girl suffering from the effects of love, erotic melancholy” (Camden, 1964, p. 254). However, with the development of feminist movement, the turn of the nineteenth to the twentieth century witnessed an advocation for women's economic independence. Women had a greater voice in the society and their domestic lives. In addition, before the nineteenth century, writing was not regarded as a decent profession. In an era when women were not even granted the right to education, it was generally believed that writing would corrupt the mind of women, who might cause social instability. But with the budding of feminist movement, the traditional discrimination against women writers was overthrown by feminists in an attempt to regain women's voice lost in the patriarchal history. Women not only picked up their pens to usher their own voice, but also experimented in writing through "new words, new spellings, new grammatical constructions, new images and metaphors” (Flotow, 2004, p. 15). For feminist writers like Gilman who were independent economically and mentally, their shared purpose was to break away from the patriarchal discourse, "making women visible and resident in language and society” (Flotow, 2004, p. 28). From this perspective, it might be easier to understand the radical reaction of the narrator in her revolt against the potential lost of self-control.

\section{Conclusion}

In conclusion, from the perspectives of feminist criticism and historical analysis, the paper attempts to argue that the first person narrator in "The Yellow Wallpaper" is a modern signifier of the archetypal Ophelia as the sacrificial lamb of the patriarchal oppression, but Ophelia and "I" differed from each other in their madness and struggle. Unlike Ophelia's submission to her gendered roles assigned by the male order, which doomed her 
self-destruction and loss of female subjectivity, the narrator in "The Yellow Wallpaper" went mad as a form of radical revolt against the patriarchal deprivation of her female identity. Such a difference, when explored within the framework of historical analysis, could be better understood from the specific historical and social backgrounds of the seventeenth century Elizabethan period and the American society during the late nineteenth to early twentieth century.

\section{References}

Beauvoir, S. de. (1949). Le deuxieme sexe (The second sex). Paris: Gallimard.

Camden, C. (Spring, 1964). On Ophelia's madness. Shakespeare Quarterly, 15(2), 247-255.

Chesler, P. (1989). Women and madness. San Diego: Harcourt Brace Jovanovich.

Fiero, G. K. (2006). The humanistic tradition: Book 3 (6 Vols. 5th ed.). New York: McGraw-Hill.

Flotow, L. von. (2004). Translation and gender: Translating in the "Era of Feminism". Shanghai: Shanghai Foreign Language Education Press.

Gilbert, S. M., \& Gubar, S. (1984). The madwoman in the attic: Woman writer and the nineteeth-century literary imagination. New Haven: Yale University Press.

Gilman, C. P. (1998). Women and economics. Mineola, New York: Dover Publications Inc.

Gilman, C. P. (2007). The yellow wallpaper. In J. LI (Ed), Myths in American culture (Graduate Course in American Studies).

Humm, M. (Ed. \& Introd). (1992). Feminisms: A reader. New York \& London: Harvester Wheatsheaf.

Parshley, H. M. (Trans. \& Ed.). (1952). The second sex. New York: Vintage Books.

Selden, R. (1989). A reader's guide to contemporary literary theory. New York: Harvester Wheatsheaf.

Shakespeare, W. (1992). Hamlet. New York: Dover Publications, Inc.

Todd, J. (1988). Feminist literary history. New York: Routledge.

Tyson, L. (1999). Critical theory today: A user-friendly guide. New York \& London: Garland Publishing, Inc.

Wright, E. (Ed.). (1992). Feminism and psychoanalysis: A critical dictionary. Oxford: Basil Blackwell Ltd. 